\title{
On Associative Meanings of Medicinal Traditional Fruits: A Semantico-Pragmatic Perspective of Local-Cultured Environmental Richness
}

\author{
Yuliana Setyaningsih, Kunjana Rahardi
}

\begin{abstract}
This research studies the associative meanings contained in the traditional medicinal fruits found in Indonesia. The object of research is not the benefits of the traditional medicinal fruits to cure any diseases. Instead, the research objective is the associative meanings contained in the traditional medicinal fruits. The perspective used in this research is the semantico-pragmatics theory. The research results show that the names of fruits found in various regions in Indonesia has associative meanings, such as iconic, collocative, affective, social, and reflective. The associative meanings are found in the traditional medicinal fruits, such as mengkudu, permot, tin, parijoto, leunca, kalaloyang, manggis, mahkota dewa, berunuk, cermai, delima, takokak, and jarak. This research contributes to the following purposes: (1) preserving the local wisdom values found in traditional medicinal fruits; (2) providing socio-cultural documentation of traditional medicinal fruits in various regions in Indonesia; (3) developing the study in the semantic-pragmatic field.
\end{abstract}

Keywords: Associative meanings, medicinal traditional fruits, semantico-pragmatic, natural richness

\section{INTRODUCTION}

Indonesia is an archipelago consisting of thousands of islands with diverse cultural and social backgrounds. To unite these diverse societies and cultures, the Indonesian language is chosen as a national language over the local vernaculars used in regions in Indonesia [1], [2]. The various manifestations of language as a result of various cultural backgrounds are in line with Sapir and Wolf's perspective that language, culture, and society are interconnected.

The interconnectedness of these three elements is formulated in the strong hypothesis or the weak hypothesis of language and culture. The strong hypothesis says that language is determined by culture, while the weak hypothesis says that language is influenced by culture [3], [4]. The debate over the essential truth between these two hypotheses never ends and each hypothesis has its own justification. For example, in the Javanese culture, there are four variants of "rice”, namely beras 'husked rice', padi 'unhusked rice', nasi

Revised Manuscript Received on December 12, 2019.

* Correspondence Author

Yuliana Setyaningsih* Master Program of Indonesian and Literature Education, Faculty of Teachers' Training and Education, Sanata Dharma University, Yogyakarta, Indonesia.Email: yuliapbsi@gmail.com

Kunjana Rahardi, Master Program of Indonesian and Literature Education, Faculty of Teachers' Training and Education, Sanata Dharma University, Yogyakarta, Indonesia. Email: kunjana.rahardi@gmail.com

(C) The Authors. Published by Blue Eyes Intelligence Engineering and Sciences Publication (BEIESP). This is an open access article under the CC BY-NC-ND license (http://creativecommons.org/licenses/by-nc-nd/4.0/) 'cooked rice', and dedak 'rice brans', and many more in other regions in Indonesia [5], [2].

However, in British English and American English, the word to describe rice is just 'rice'. The same thing applies to the words associated with kelapa or 'coconut' in the Javanese culture, such as the names 'kelapa', kelapa muda 'young coconut', kelapa tua 'old coconut', manggar 'coconut flower, bluluk 'coconut unripe fruit', cengkir 'young coconut', and many more. However, in British English, American English, or Australian English, the word to refer to coconut is 'coconut' [6].

On the other hand, in Eskimo, the word to refer to 'snow' varies, which is not known to anyone living outside the Eskimo who does not know 'snow'. This confirms that language is determined by the society and culture where the language is spoken. The social and cultural components and aspects in a certain region will greatly influence the linguistic manifestation of the language in the region in question [7], [2].

This is a very interesting research topic to explore, not only from ecolinguistic, envirolinguistic, or anthropolinguistic perspectives, but also from the semantico-pragmatic perspective. This research discusses in particular the associative meanings found in the traditional medicinal fruits grown in various regions in Indonesia. The object of research is not the benefits of traditional medicinal fruits, but their associative meanings.

The perspective used in this research is the semantico-pragmatics theory. The theory can be simply said as a transitional theory from semantics which is a purely part of linguistics, and pragmatics as a field outside of linguistics [8], [9]. Semantics is related to the dimensions of the internal context of language, while pragmatics is related to the dimensions of the external context of language. Semantico-pragmatic research is at the center of the two extremes of science, namely semantics on one side and pragmatics on the other [10].

This semantico-pragmatic perspective research contributes in: (1) preserving the local wisdom values contained in traditional medicinal fruits; (2) providing socio-cultural documentation related to traditional medicines in the form of names of fruits from various regions; (3) developing the study in the semantic-pragmatic field.

Research on the associative meanings contained in traditional medicinal fruits uses the semantic theory and pragmatic theory as its basic design. Semantics is a linguistic study of meaning. The meaning studied in semantics is dyadic.

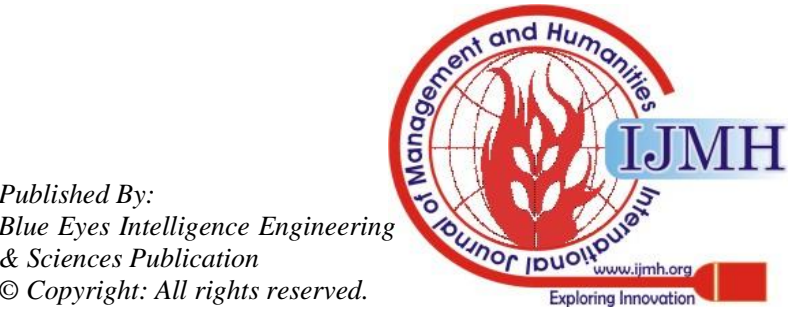




\section{On Associative Meanings of Medicinal Traditional Fruits: A Semantico-Pragmatic Perspective of Local-Cultured Environmental Richness}

It means that the meaning is only based on the object as a referent [11], [12].

The context in semantic studies is not considered, because semantic studies first aim to find the conceptual meaning of a linguistic entity. Since the purpose of a semantic study is the conceptual meaning, the discussion of contexts will actually obscure the essence of the study [13]. The development of diachronic branches of linguistics called semantics continues, and by the 1970s, when the perspective of language as a single entity was abandoned, semantic theories developed to accommodate the context called the semantico-pragmatics [14].

This new semantic theory eventually developed into a new branch, and in parts of the United States this theory developed into a stream. Therefore, in the semantico-pragmatics stream, there is a study of associative meaning. In the study, the context gets a special attention. So instead of being a conceptual meaning in semantics, it becomes a contextual meaning in semantico-pragmatics. The contextual meaning in Leech's perspective is referred to as the associative meaning [15], [2]. In his view, associative meaning can be divided into four, namely the collocative meaning, affective meaning, social meaning, connotative meaning, and reflective meaning.

Collocative meaning is intertwined with the collocation ability of linguistic form [16]. For example, this collocative meaning of the fruit jambu air "water apple" (Syzygium aqueum) which is different from jambu biji "common guava" (Psidium guajava). That is, the meaning of the fruit jambu air and jambu biji is strongly influenced by the ability of the collocation of the words air and the word biji in the word jambu. The affective meaning is related to the sense value of a linguistic entity [17].

In Javanese in Indonesia, for example, affective words are often found because Javanese cultural background is very influential in the naming of things. For example the words siji 'one' and sitok 'just one' actually have the same referent, but both forms of language have different emotive values [18]. Likewise, the forms ora, or 'no' used among people of equal status, and mboten, or polite "no" said to someone of a higher social status, in Javanese have the same meaning referents, but both have different affective meanings.

Furthermore, social meaning is understood as an arbitrary. It means that the naming of certain linguistic entities does not have a referential relationship with what they mean [19]. For example the name of the fruit mundu turns out to have absolutely no connection with the referent. Likewise, the name of the fruit mengkudu cannot be traced to its affective or iconic meaning. In other words, these words are arbitrary, which is called social meaning, according to Leech. However, in the name mahkota dewa or God's crown, the naming clearly points to the associative meaning of the referent.

The next meaning is connotative meaning. In semantics, the connotative meaning is usually compared to the denotative meaning. The connotative meaning is interpretative, while the denotative meaning is lexical [20]. In relation to the names of the fruits that function as medicine, the connotative meaning is contained in the term rambutan or Nephelium Lappaceum which connotes to rambut 'hair'. Rambutan fruit skin is hairy, hence very iconic and connotative to be called the rambutan 'hairy' fruit. The last type of meaning mentioned by Leech is reflective meaning, which in other references is called iconic meaning. The iconic meaning always describes the aspects inherent in the referent [21], [5]. The linguistic aspects can range from the form, shape, smell, color, sound, and many more.

The linguistic forms that read [e] in Javanese almost certainly have negative connotations of meaning. Names like tokek and ember carry negative senses, as in 'ketek', 'belek', 'tempe', 'besek'. Other examples related to the name of traditional medicinal fruits are the names 'pete', 'pace', 'dele', etc. The theories mentioned above are used as perspectives in the research on the associative meaning of traditional medicinal fruits in this paper.

\section{RESEARCH METHODOLOGY}

The Semantico-pragmatic research on associative meanings contained in traditional medicinal fruits is a qualitative descriptive research [7]. Thus, numerical computations are not used to describe the object of research. The substantive data source of this study is the values of associative meanings contained in the traditional medicinal fruits in Indonesia, especially Java [22]. Data was obtained by applying interview techniques. The interview was conducted with a number of figures who understood the associative meanings of traditional fruits in the Javanese society and culture, especially those in Yogyakarta.

The researchers themselves can also function as a source of substantive data for this study because they intuitively have close lingual and cultural distances related to the object of this study. In addition, this research data is also taken from texts that describe associative meanings of traditional medicinal fruits. The research data was collected by the observation method, i.e. observing texts containing descriptions of the associative meanings of traditional fruits that could be reached within the timeline of the study. The techniques used to apply the observation method in this research are the recording and the note-taking techniques. In addition to the observation method, to collect research data also used the speaking method, or commonly known as the interview method [23], [24].

The collected data was further classified and typified according to the types and classes. The next step taken by the researchers was to conduct an analysis and interpretation of the data that has been classified and typified. Data analysis was performed using the distributional analysis method and the content analysis method. The results of the data analysis were then triangulated to local wisdom experts and / or cultural experts who are competent in their fields, to ensure that the analysis and interpretation carried out by the researcher were correct and correct and met the validity requirements.

\section{RESULTS AND FINDINGS}

In this study, the names of 20 traditional medicinal fruits useful to cure diseases contain associative values from the semantico-pragmatic perspective. The next section presents the traditional fruits one by one.

\section{A. Buah Mengkudu or Morinda citrifolia, known as Indian \\ mulberry, noni, and cheese fruit}




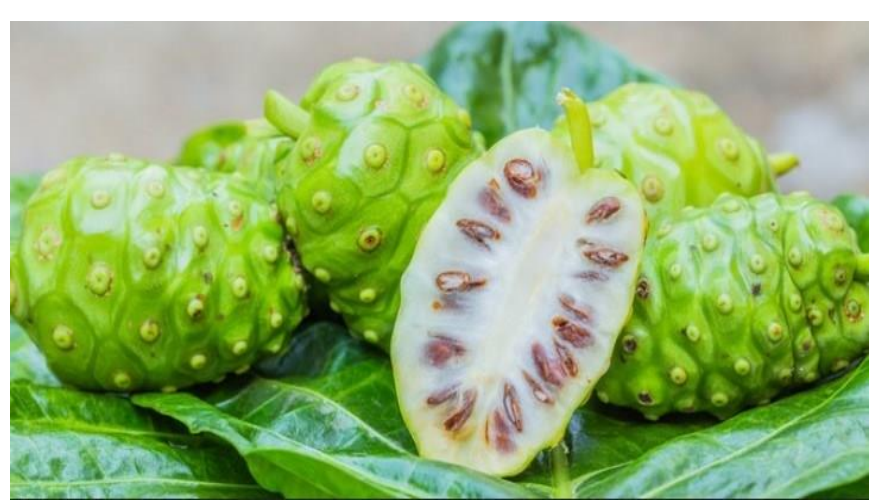

(http://kampoengilmu.com/tanaman-herbal/)

Figure 1. Buah Mengkudu or Morinda citrifolia

In the Javanese society, mengkudu or noni fruit has many benefits for treating various diseases. Noni is also very easy to find in various regions because it grows as a hedge plant. Several studies found that noni fruit contains antioxidant, stimulates the immune system and resists tumors and cardiovascular disease. Linguistically, the name mengkudu has no special meaning. In Javanese, this fruit is called 'pace'. This Javanese word contains an iconic dimension because usually Javanese words which contain [e] sound have negative, ugly, unpleasant connotations, and so on. Thus, in terms of semantico-pragmatics, the meaning of the fruit mengkudu has a 'social meaning', the meaning that is arbitrary. However, in Javanese the name 'pace' has the reflective or iconic meaning.

\section{B. Buah Tin or ficus carica or a common fig}

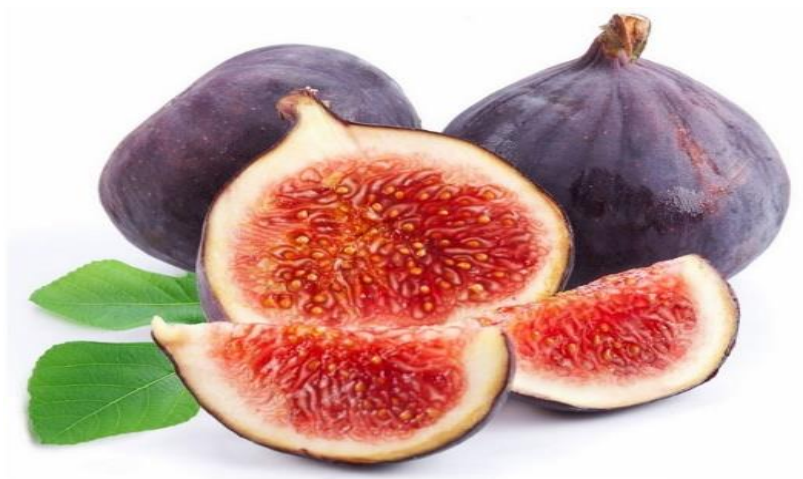

(https://kabartani.com/inilah-manfaat-dan-khasiat-buah-tin-b agi-kesehatan.html)

Figure 2. Buah Tin or ficus carica

From the data sources accessible to the research team, buah tin or figs have many health benefits. Figs are often used for milk production, while for Arabs, fig is very useful to overcome menstrual pain. The efficacy of the fig is produced from its high nutritional content, including its protein, mineral, vitamin, iron, and calcium content. The semantico-pragmatic study conducted by the research team on the naming of traditional fruits found that the name 'tin' has a connotative associative meaning. The sound [i], in Javanese, contains the meaning 'small'. The contents of buah tin are also small and delicate, as indicated by its associative meaning 'small'. Thus, it can be stressed that the name of buah tin is an iconic associative in the Semantico-pragmatic dimension.

\section{Tanaman Permot or Passiflora foetida or bush passion fruit}

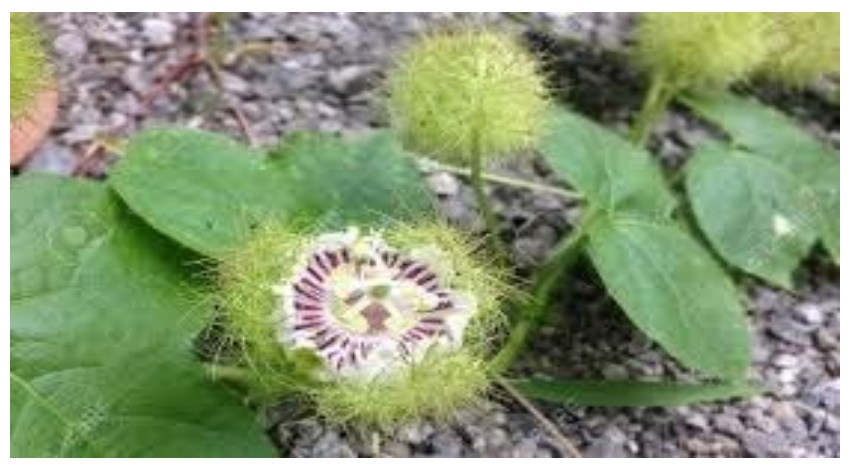

(https://www.pusakapusaka.com/khasiat-tanaman-permot-u ntuk-pengobatan-alami.html)

Figure 3. Tanaman Permot or Passiflora foetida

From observing the texts available for the research team, the benefits of buah permot include the reducing inflammation. In addition, buah permot is also very good for coughing, high blood pressure, diabetes, etc. Linguistically, the names of these fruits have no special meaning. Thus, it can be stressed that the name has a social associative meaning. In other words, the naming of the traditional medicinal fruit is arbitrary from the semantico-pragmatic dimension.

\section{Buah Parijoto or Medinilla magnifica or rose grape}

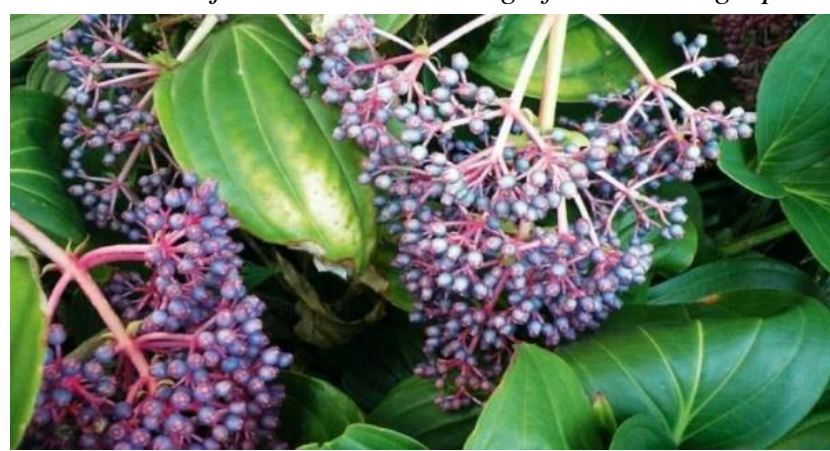

(https://www.kaskus.co.id/thread/5ca0478eeaab251bca4454 9f/5-fakta-menarik-buah-parijoto-tanaman-hias-sekaligus-ob at-herbal/)

\section{Figure 4. Buah Parijoto or Medinilla magnifica}

Buah parijoto has benefits for maintaining the health of pregnant women. These fruits are also very good for maintaining baby's health and beautiful appearance. For high cholesterol patients, buah parijoto is also very useful to control it. A semantico-pragmatic study conducted by the research team shows that the name of this traditional medicinal fruit is connotative. The word parijoto in Javanese means the blooming rice. In Javanese, such rice plants are called mratak or blooming. Pragmatically, the blooming rice competes to become parijoto before finally turning yellow and ready to be harvested and hulled, which is identical to the process of finding one's identity. Every person actually undergoes a certain process to seek and finally find their true identity in life. The naming of buah parijoto, in this case, cannot be separated from the philosophy of life.

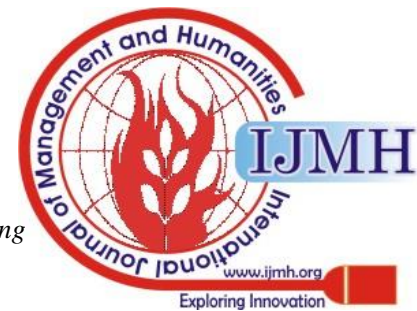


E. Buah Kalaloyang atau Gorek or Guilandina bonduc, commonly known as nicker bean

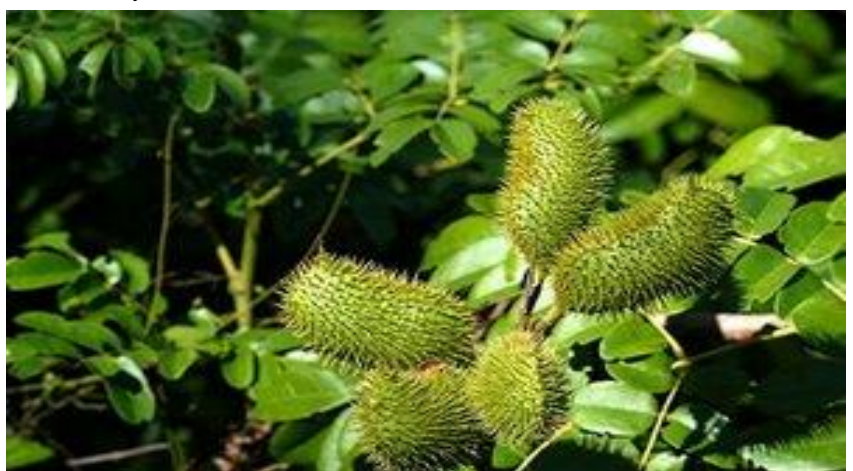

(https://www.bukalapak.com/p/kesehatan-2359/obat-suplem en/obat-obatan/w6sfcc-jual-buah-kalaloyang-atau-buah-gore

k)

Figure 5. Buah Kalaloyang atau Gorek

Semantico-pragmatically, the name of the buah Kalaloyang or Gorek is iconic. This name reflects something. Gorek means a scratch of fire. The skin appearance of gorek seen in the picture above has implications for flaming fire. Thus it can be stressed that based on its shape, the fruit gorek is iconic or emblematic. From the dimensions of health benefits, this fruit is useful for treating the following diseases: diabetes, hypertension, kidney, heart, gout, asthma, etc.

F. Buah Mahkota Dewa or Phaleria macrocarpa, known as God's crown

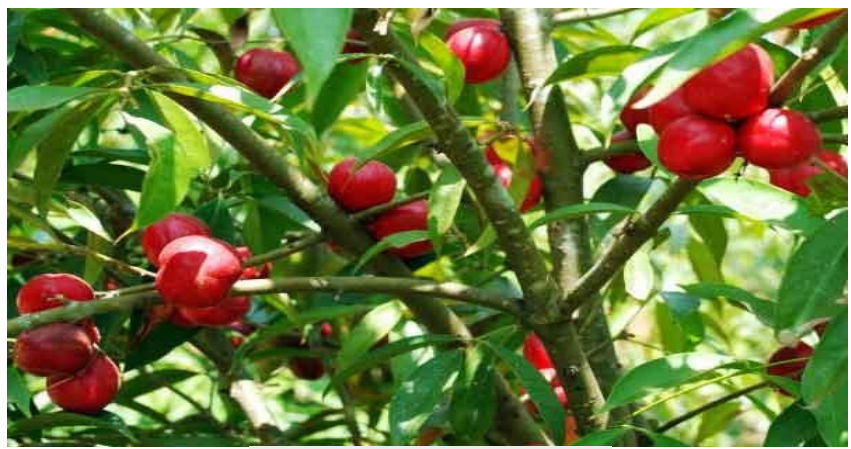

(Foto: okutimurkab.go.id)

(http://www.satuharapan.com/read-detail/read/mahkota-dew a-buah-simalakama-si-raja-obat)

Figure 6. Buah Mahkota Dewa or Phaleria macrocarpa

From the semantico-pragmatic dimension, the fruit mahkota dewa is affective associative. In other words, the name of the fruit contains the value of senses. The value of senses in question is the value of elegance because it has something to do with 'gods', as shown in the word 'crown' worn by the gods. Functionally, the name of this traditional fruit also is iconic in terms of the health benefits, because it heals illnesses classified as severe as cancer, heart disease, diabetes, and the like. In the context of wayang or shadow puppets, 'god' or 'bathara' also has a heavy duty to control the course of the universe. Thus it is clear that the naming of Mahkota Dewa is related to the value of senses, which is affective associative. The dimension of iconicity is also inherent in naming of the traditional medicinal fruit.

\section{G. Buah Leunca or Solanusm nigrum, known as blackberry} nightshade

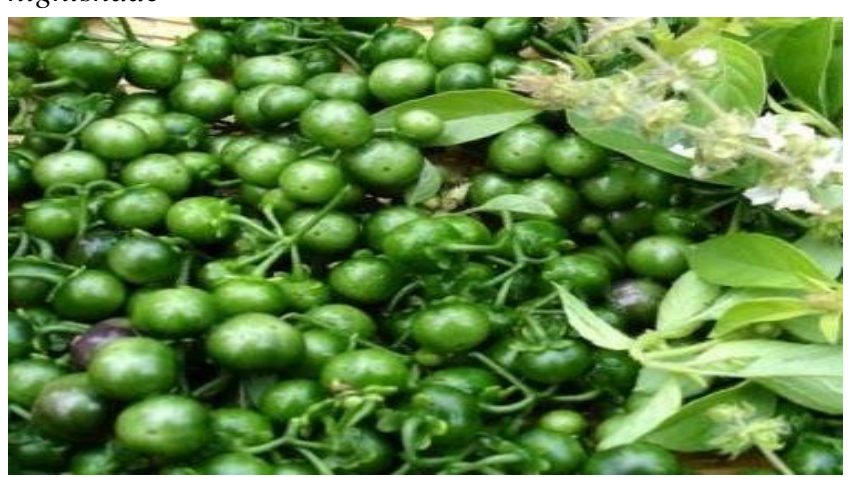

(http://www.agrobisnisinfo.com/2016/01/manfaat-tanamanbuah-leunca-untuk.html)

Figure 7. Buah Leunca or Solanusm nigrum

Leunca fruit in the Javanese and Sundanese society is very useful to help treat minor ailments. In Javanese, this fruit is referred to as woh ranti or Solanus americanum Mill, whose connotations refer to their numerous small seeds. Semantico-pragmatically, the naming of the fruit leunca or ranti is reflective or iconic. The shape of the berries are small and numerous, as echoed in the Javanese words 'woh ranti'.

\section{H. Buah Manggis or Garcinia mangostana or known as} mangosteen

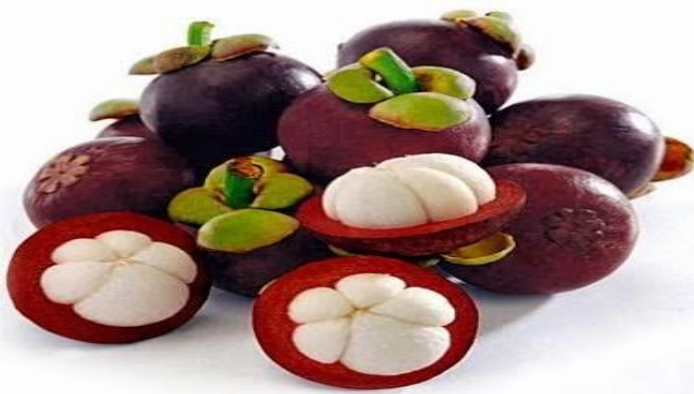

(http://www.mediatanews.com/artikel/739-3-tanaman-obatpenghancur-batu-empedu)

Figure 7. Buah Manggis or Garcinia mangostana

Buah manggis tastes very sweet. It also tastes sour, which sometimes causes anyone eating it to frown, or pucker their lips. This fruit is said to be an extraordinary fruit because it could heal cancer. Mangosteen rind is also very beneficial to cure diseases such as high blood pressure, high cholesterol, and heart disease. From the semantico-pragmatic dimension, the name of the buah manggis is social or arbitrary. It has a social associative meaning because the name, shape, taste, smell, benefits, etc. of the fruit are not necessarily linked to their meaning. Thus, from the linguistic dimension, the names of these fruits are not iconic but rather arbitrary.

I. Buah Cermai or Phyllanthus acidus, known as Malay gooseberry
Published By:

Blue Eyes Intelligence Engineering \& Sciences Publication

(C) Copyright: All rights reserved.

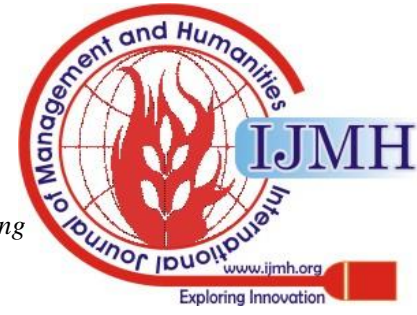




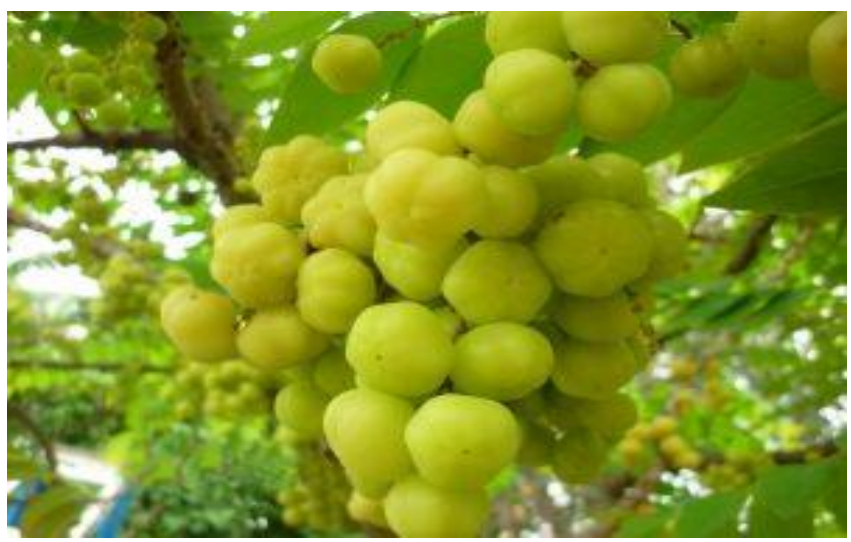

(https://samudrabibit.com/tanaman-buah-cermai/)

Figure 8. Buah Cermai or Phyllanthus acidus

Buah cermai is very useful for treating constipation. In addition, this fruit is also useful for cancer treatment. This fruit tastes very sour and is often made into sweet cured prunes to be consumed. A semantico-pragmatic study conducted by the research team shows that the name of this traditional fruit is social associative. In other words, the naming of this fruit is arbitrary because the name has no distinctive relationship with the referent.

\section{J. Buah Delima or Punica granatum, known as} pomegranate

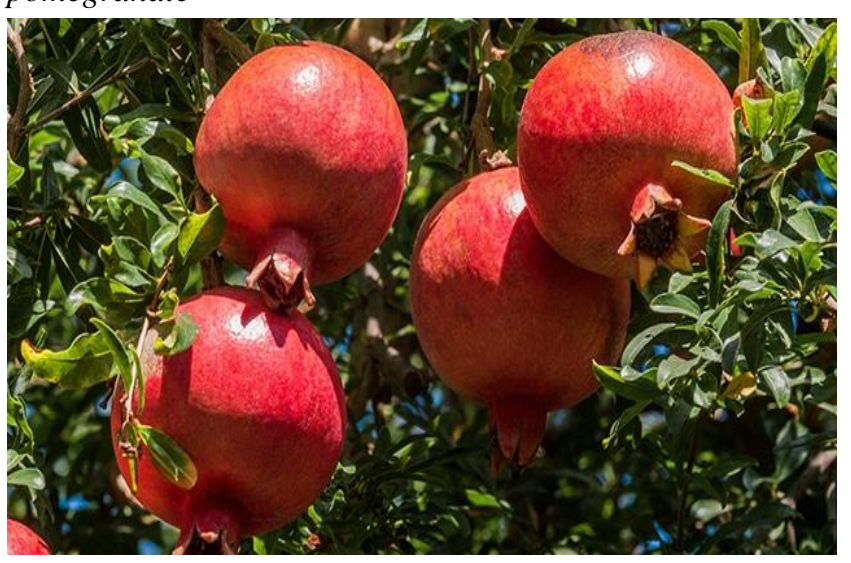

(https://www.greeners.co/flora-fauna/delima-si-buah-maniskaya-khasiat/)

Figure 9. Buah Delima or Punica granatum

The name buah delima does not contain any iconic meaning. Likewise, it does not show the specific meaning associations of the naming of this traditional fruit. Thus, from the linguistic dimension, especially semantico-pragmatics, this naming is arbitrary. In linguistic studies, not all words in a language are associative. Most of the time, the naming is based on convention. As for buah delima, semantico-pragmatically, there are no associative dimensions they have. From the texts available to the researchers, buah delima contains many health benefits, such as to treat heart disease, cancer, diabetes, etc. The name of this beautiful fruit is also used in proverbs, for example in Malay saying, 'bagai delima merekah' or 'as a blossoming pomegranate' to describe the resemblance of two persons' faces. It is more like "like two peas in a pod."

K. Buah Berenuk or Crescentia cujete, known as Calabash tree

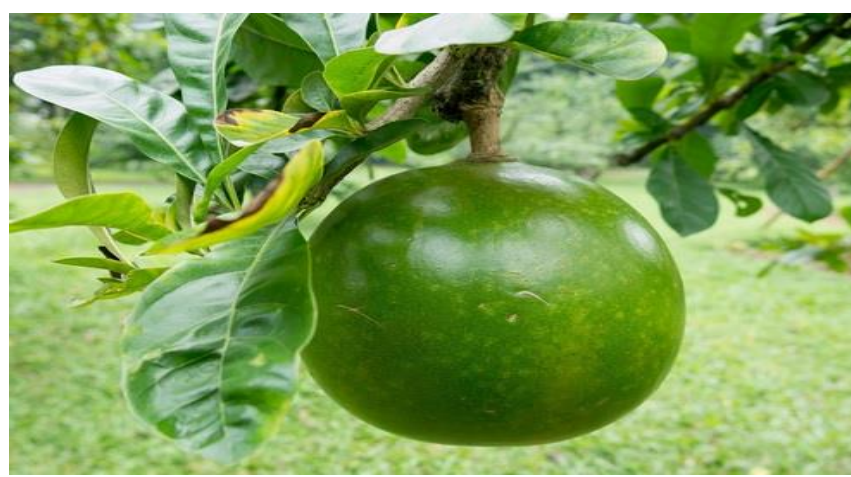

(https://manfaat.co.id/manfaat-buah-berenuk)

Figure 10. Buah Berenuk or Crescentia cujete

The research team found that the name of the buah berenuk is iconic. The iconic element is the the pronunciation of the fruit. In the pronunciation, the fruit contains the sound [u] which connotes to something 'big and round'. Linguistically, the pronunciation of $[u]$ is not too different from the pronunciation of [o] which also requires a rounded mouth. Thus, it can be emphasized that semantico-pragmatically, the buah berenuk has a reflective or iconic meaning. Based on the texts observed by the research team, buah berenuk is useful for maintaining healthy body in general. Because of its great health benefits, this fruit has even been made as the mascot of a particular city.

L. Buah Ciplukan or Physalis angulata, known as angular winter cherry

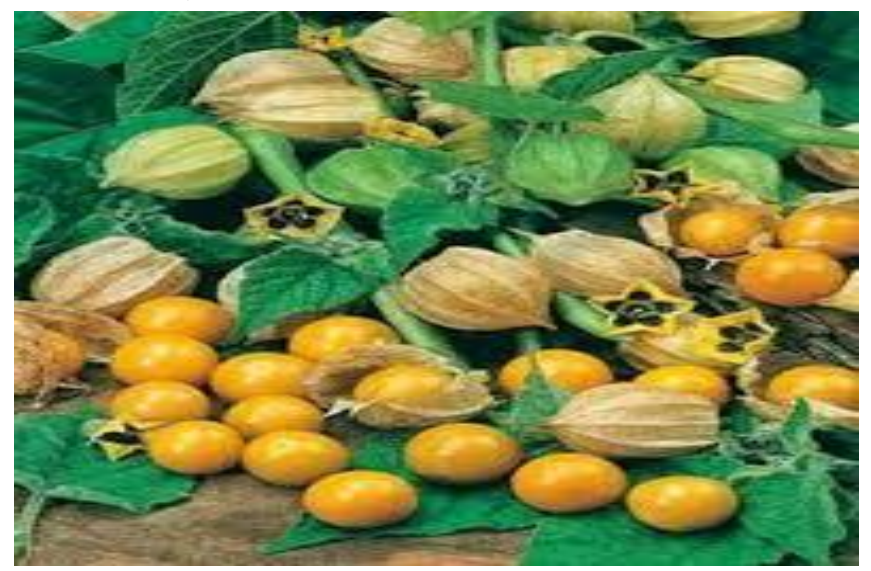

(https://www.facebook.com/357494238044763/photos/mani ss-buahnya-1000-manfaatnya/359717801155740/)

Figure 11. Buah Ciplukan or Physalis angulata

The ciplukan or ceplukan has great health benefits. In the past, many of these plants grew in the gardens as small shrub berries. The trunk is branched, and the fruit is small but nyempluk or plumpy. Therefore the name of this fruit is ciplukan. From a semi-pragmatic perspective, the name of this traditional fruit is iconic associative. Aside from being iconic, the traditional medicinal fruit also has an affective meaning. That is, there is a value of senses carried by the name ciplukan or ceplukan.

M. Buah Takokak or Solanum torvum, known as turkey berry

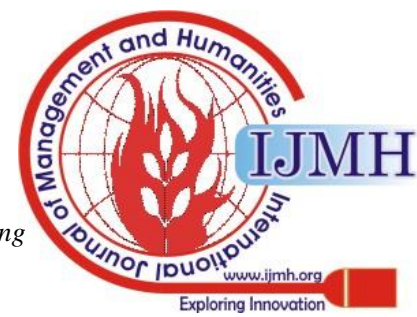




\section{On Associative Meanings of Medicinal Traditional Fruits: A Semantico-Pragmatic Perspective of Local-Cultured Environmental Richness}

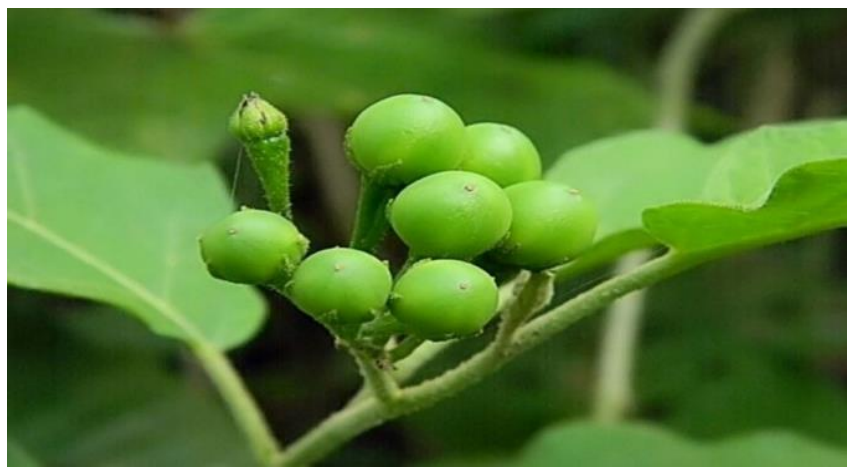

(https://www.inibaru.id/indo-hayati/takokak-kecil-dan-pahit -tapi)

Figure 12. Buah Takokak or Solanum torvum

Buah takokak has a number of health benefits. Minor illnesses such as flu, inflammation, ulcers, and the like can be treated with this traditional medicinal fruit. From the semantico-pragmatic dimension, the research team found that the name of this traditional fruit was social or arbitrary. The naming has no relationship with the referent's name. Some experts say that not all words in a language are iconic. Many linguistic words are considered arbitrary based on social conventions. In the case of buah takokak, the associative meaning is social and conventional.

\section{N. Buah Jarak or Jatropha curcas L., Euphorbiaceae, known as castor oil plant}

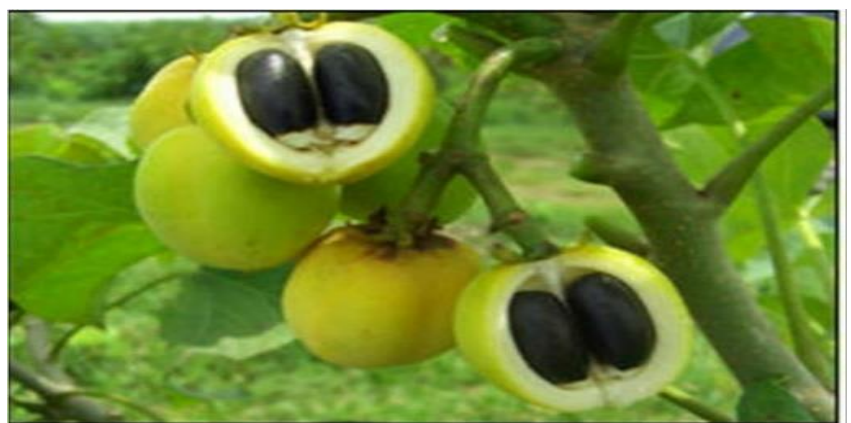

(https://www.bukalapak.com/p/hobi-koleksi/berkebun/bibittanaman/33t0bt-jual-biji-benih-buah-tanaman-jarak-pagar)

Figure 13. Buah Jarak or Jatropha curcas

Buah jarak is a hedgerow plant. It means that this plant is often used as a fence to confine one's territorial areas. Buah jarak is useful for treating constipation, skin ailments, and also beneficial for the health of male organs. From the semantico-pragmatic dimension, the name of this traditional fruit is social associative. The naming of this traditional medicinal fruit is arbitrary.

\section{CONCLUSION}

The results showed that the names of fruits in various regions of Indonesia had associative meanings, iconic, collocative, affective, social, and reflective. These associative meanings are contained in traditional medicinal fruits such as mengkudu, permot, tin, parijoto, leunca, kalaloyang, manggis, mahkota dewa, berenuk, ciplukan, delima, takokak, and jarak. This research will contribute in: (1) preserving the values of local wisdom contained in traditional medicinal fruits; (2) providing socio-cultural documentation related to traditional medicines in the form of names of fruits from various regions; (3) developing the study in the semantic-pragmatic field.

\section{REFERENCES}

1. N. P. Putri, "Eksistensi Bahasa Indonesia pada Generasi Millennial," Widyabastra, 2017.

2. R. K. Rahardi, "Pragmatic Perspective on Phatic Functions and Language Dignity," Int. J. Eng. Adv. Technol., vol. 8, no. 5C, May 2019, pp. 261-268, 2019.

3. V. Roudometof, "Theorizing glocalization: Three interpretations," Eur. J. Soc. Theory, 2016.

4. A. Duranti, Linguistic Anthropology. 1997.

5. R. K. Rahardi, Setyaningsih, Y. "Contextualizing Local Values of Children's Games in the Perspective of Ecopragmatics to Enhance Culture-Specific Based Communication," Int. J. Eng. Adv. Technol., vol. 9, no. Issue-1, October 2019, pp. 143-151, 2019.

6. S. G. J. N. Senanayake, "Indigenous knowledge as a key to sustainable development," J. Agric. Sci., 2016.

7. L. Science et al., "An Introduction to Discourse Analysis: Theory and Method," J. Pragmat., 2017.

8. C. Bezzi, "Evaluation Pragmatics," Evaluation, 2006.

9. Z. Salzmann, A. Duranti, and C. Goodwin, "Rethinking Context: Language as an Interactive Phenomenon," Language (Baltim)., 1993.

10. J. Murray, D. Morgenstern, G. Furstenberg, and T. Athena, "Critical Concepts in Linguistics," Foundations, 2009.

11. C. Goodwin and A. Duranti, "Rethinking Context: an introduction," in Rethinking Context. Language as an interactive phenomenon., 1997.

12. D. Schiffrin, "Discourse Markers: Language, Meaning, and Context," in The Handbook of Discourse Analysis, 2008.

13. D. Farkas and H. de Swart, "The semantics and pragmatics of plurals," Semant. Pragmat., 2010.

14. N. B. Ratner, "First language acquisition," in International Encyclopedia of Education, 2010.

15. J. Chen, "Research Trends in Intercultural Pragmatics," Aust. J. Linguist., 2017.

16. S. P. Wang, "Corpus-based approaches and discourse analysis in relation to reduplication and repetition," Journal of Pragmatics. 2005.

17. M. Takimoto, "Metapragmatic discussion in interlanguage pragmatics," J. Pragmat., 2012.

18. M. Ephratt, "The functions of silence," J. Pragmat., 2008.

19. A. Lascarides and A. Copestake, "Pragmatics and word meaning," J. Linguist., 1998.

20. K. Allan, "The pragmatics of connotation," J. Pragmat., 2007.

21. J. Aitchison, "An introduction to cognitive linguistics," J. Pragmat., 1999.

22. Sudaryanto, Metode dan Aneka Teknik Analisis Bahasa: Pengantar Penelitian Wahana Kebudayaan secara Linguistis, 1st ed. Yogyakarta: Sanata Dharma University Press, 2015.

23. Y. Setyaningsih and R. K. Rahardi, "Quality Of Arguments Used In The First-Round Presidential Debate: Critical Pragmatics And Stephen Toulmin's Perspective," Int. J. Eng. Adv. Technol., vol. 8, no. 5C, pp. 716-725, 2019.

24. J. Schilling, "On the pragmatics of qualitative assessment designing the process for content analysis," Eur. J. Psychol. Assess., 2006.

25. https://www.bukalapak.com/p/hobi-koleksi/berkebun/bibit-tanaman/3 3t0bt-jual-biji-benih-buah-tanaman-jarak-pagar

26. https://www.inibaru.id/indo-hayati/takokak-kecil-dan-pahit-tapi

27. https://www.facebook.com/357494238044763/photos/maniss-buahny a-1000-manfaatnya/359717801155740/

28. https://kabartani.com/inilah-manfaat-dan-khasiat-buah-tin-bagi-keseh atan.html

29. https://www.kaskus.co.id/thread/5ca0478eeaab251bca44549f/5-faktamenarik-buah-parijoto-tanaman-hias-sekaligus-obat-herbal/

30. https://www.pusakapusaka.com/khasiat-tanaman-permot-untuk-pengo batan-alami.htm

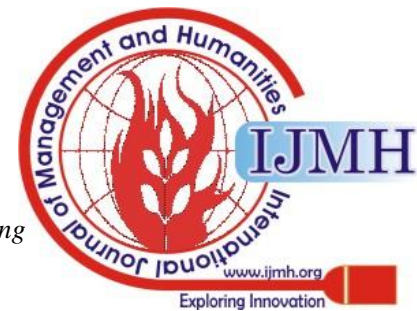




\section{AUTHORS' PROFILE}

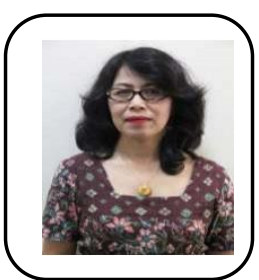

Dr. Yuliana Setyaningsih, M.Pd., was born in Surakarta on October 1, 1963. She serves as the Lecturer of Indonesia Language and Literature Education Study Program, Faculty of Teachers Training and Education, Sanata Dharma University, Yogyakarta. She served as the Head Department of the Indonesian and Literature Study Program for two periods starting from 2009 until 2017. She graduated from the Doctorate Program of Indonesian Education University in Indonesian Education Teaching Study Program in January 2007. The textbooks during her doctorate tenure are: Fonologi dalam Bahasa Indonesia (Universitas Sanata Dharma Press, Yogyakarta, 2014), Pragmatik: Fenomena Ketidaksantunan Berbahasa (Erlangga Publisher Jakarta, 2016) as the co-writer, Menulis Artikel Jurnal: Panduan Mencipta Karya Ilmiah Bermutu dengan Pengembangan Argumentasi Berperspektif Stephen Toulmin (Amara Books Publisher Yogyakarta, 2018) Model Peningkatan Kualitas Argumen Paragraf-paragraf Argumentatif Bagian Pembahasan Artikel Jurnal Terakreditasi, Amara Books Publisher Yogyakarta, 2017), Kefatisan Berbahasa: Studi fenomena kebahasaan dalam perspektif sosiokultural dan situasional, Amara Books Publisher Yogyakarta, 2017) as the co-writer. She did her thoughts in Indonesian Language Teaching, Evaluation, Curriculum Development, and Critical Writing based on Toulmin's Model and they have been exposed in various national and international forums documented in various proceedings and journal articles.

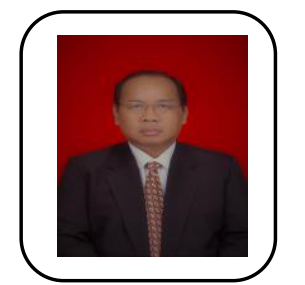

Dr. Kunjana Rahardi, M.Hum., was born in Yogyakarta on October 13, 1966. He serves as the Head of Master Program in the Indonesian Language and Literature Education, Faculty of Teachers Training and Education, Sanata Dharma University, Yogyakarta. He graduated from the Doctorate Program of Gadjah Mada University in linguistics in 1999. The linguistic textbooks during his doctorate tenure are: Pragmatik: Kesantunan Imperatif dalam Bahasa Indonesia (Erlangga Publisher Jakarta, 2006), Asyik Berbahasa Jurnalistik: Kalimat Jurnalistik dan Temali Masalahnya (Santusta Publisher Yogyakarta, 2006), Paragraf Jurnalistik: Menyusun Alinea Bernilai Rasa dalam Bahasa Laras Media (Santusta Publisher Yogyakarta, 2006), Dasar-dasar Bahasa Penyuntingan Media [Gramata Publisher Jakarta, 2009], Penyuntingan Bahasa Indonesia untuk Karang-mengarang [Erlangga Publisher Jakarta, 2009], Menulis Artikel Opini dan Kolom di Media Massa (Erlangga Publisher Jakarta, 2012), Fonologi dalam Bahasa Indonesia (Universitas Sanata Dharma Press, Yogyakarta, 2014), Sosiopragmatik [Erlangga Publisher Jakarta, 2009 Kajian Sosiolinguistik Kode dan Alih Kode (revised edition) (Ghalia Publisher Indonesia, Jakarta, 2010, 2015), Bahasa Indonesia Perguruan Tinggi: Mata Kuliah Pengembangan Kepribadian (Erlangga Publisher Jakarta, 2010), Bahasa Jurnalistik: Pedoman Kebahasaan untuk Mahasiswa, Jurnalis, dan Umum (Ghalia Publisher Indonesia, Jakarta, 2010; 2015), Pragmatik: Fenomena Ketidaksantunan Berbahasa (Erlangga Publisher Jakarta, 2016), Pragmatik: Fenomena Kefatisan Berbahasa dalam Perspektif Sosio-kultural dan Situasional (Erlangga, Jakarta 2018). He did his thoughts in pragmatics and its interesting sides have been exposed in various nasional and international forums documented in various proceedings and journal articles. He did the research consecutively for five years (in 2013 until 2015 and in 2016 until 2018) on Impoliteness in Indonesian Language and on Phatic Communion in Indonesian Language with the grants given by Directorate of Research and Community Service, Ministry of Research, Technology and Higher Education, Republic of Indonesia. 